\title{
Influence of conjugated linoleic acid (CLA) or tetradecylthioacetic acid (TTA) on growth, lipid composition, fatty acid metabolism and lipid gene expression of rainbow trout (Oncorhynchus mykiss L.)
}

Sean R. Kennedy ${ }^{\mathrm{a}, *}$, Ralph Bickerdike ${ }^{\mathrm{b}}$, Rolf K. Berge ${ }^{\mathrm{c}}$, James R. Dick ${ }^{\mathrm{a}}$ and Douglas R. Tocher $^{\mathrm{a}}$

${ }^{a}$ Institute of Aquaculture, University of Stirling, Stirling FK9 4LA, UK

${ }^{b}$ BioMar Ltd., Grangemouth Docks, Grangemouth FK3 8UL, Scotland, UK.

${ }^{c}$ Institute of Medicine, Section of Medical Biochemistry, Haukeland University Hospital,N-5021 Bergen, Norway.

Keywords: CLA; TTA; lipid; fatty acid; composition; liver; flesh; rainbow trout

*, Correspondence to: Sean R Kennedy, Institute of Aquaculture, University of Stirling, Stirling FK9 4LA, United Kingdom. Tel. No: +44 1786 466599; Fax No: +44 1786 472133; Email: s.r.kennedy@stir.ac.uk 


\section{Abstract}

Our objective was to test the hypotheses that conjugated linoleic acid (CLA) and/or tetradecylthioacetic acid (TTA) would have beneficial effects on the nutritional quality of rainbow trout (Oncorhynchus mykiss) through decreased lipid content of flesh or viscera, and increased levels of beneficial fatty acids including accumulation of CLA or TTA themselves. The specific aims of this study were to determine the effects of CLA and TTA on growth performance, lipid and fatty acid metabolism, and selected gene expression in commercial sized trout grown in seawater. Trout were fed for eight weeks on fish meal and fish oil diets containing either $0.5 \%$ or $1 \%$ CLA, or $0.5 \%$ TTA. The effects of the supplemented fatty acids on growth, feed efficiency, lipid contents, class compositions and fatty acid compositions of

flesh and liver were determined, along with liver highly unsaturated fatty acid synthesis, activities of key enzymes of fatty acid oxidation in liver and muscle, and expression of carnitine palmitoyltransferase-I (CPT-I) and fatty acyl desaturase and elongase genes. Neither functional fatty acid had any effect on growth parameters, condition factor, viscero- and hepato-somatic indices or fillet colour, and there were no mortalities in any of the treatments. Dietary CLA, but not TTA, decreased the lipid content of liver, but neither fatty acid had any significant effect on lipid class compositions of liver and flesh. Both CLA and TTA were incorporated into tissue lipids, with higher percentages found in flesh compared to liver. In addition, production of hexaene fatty acid by liver microsomes was increased by dietary CLA or TTA, and both functional fatty acids increased the proportion of n-3 fatty acids in liver mainly due to increased 20:5n-3 and 22:6n-3. However, the expression of fatty acyl $\Delta 6$ desaturase was significantly lower in fish fed CLA or TTA, whereas the expression of PUFA elongase was increased, significantly so in fish fed $1 \%$ CLA. CPT-I activity was increased by TTA in liver and red muscle, and acyl CoA oxidase activity was increased by TTA in liver and CLA at the higher dietary inclusion level in red muscle. There was a clear trend for CPT-I expression to be increased in fish fed $0.5 \%$ CLA or TTA in all tissues although this was only significant in white muscle. The results showed that both CLA and TTA had effects on lipid metabolism that partly support the hypotheses tested. Although CLA or TTA did not enhance growth parameters, feed conversion or potential yield, nutritional quality could be enhanced, and sea-run trout fed CLA or TTA could be beneficial in the human diet through provision of bioactive fatty acids, with no detrimental effects on 20:5n-3 or 22:6n3 levels. 


\section{Introduction}

High lipid levels are utilized in commercial aquaculture diets in order to offset relatively expensive protein as a source of energy. In this way, protein can be 'spared' for synthesis of new tissue (Wilson, 1989; Bell, 1998). Although high lipid diets provide an invaluable energy source, they may also promote excessive fat deposition in tissues, including liver and flesh, which can affect the overall market quality of the fish (Sargent et al., 2002). Furthermore, an increase in the production of farmed fish over the last decade, juxtaposed with a decline in finite sources of fish oil has prompted research into alternative sustainable feed formulations, primarily examining the potential for plant-derived oil replacement (Tacon, 2003; Sargent et al., 2002). However, it has been suggested that vegetable oil replacements may also impact consumer welfare by reducing the amount of human health promoting $\mathrm{n}$ 3 highly unsaturated fatty acids (HUFA) in fish (Tocher, 2003). The physiological and biochemical influences of potential dietary "functional foods" are currently being assessed in an attempt to alleviate the deleterious consequences of feeding fish high lipid level or alternative oil diets (Kennedy et al., 2005, 2007). Two of these prospective "functional" dietary supplements are the bioactive fatty acids, conjugated linoleic acid (CLA) and tetradecylthioacetic acid (TTA).

The term CLA is used to denote positional, geometric and conjugated isomers of linoleic acid (18:2n-6), found naturally in dairy and meat produce; the two most biologically active isomers being cis-9, trans-11 and trans-10, cis-12 (Pariza et al., 2001). Dietary CLA exerts several beneficial effects on lipid metabolism in mammals and there is evidence to suggest that it can influence body composition by decreasing adiposity while increasing lean body mass in mammals (Keim, 2003). CLA has also been reported to alter the expression of a number of genes thought to be pivotal in maintaining lipid and fatty acid homeostasis (Ide, 2005). Altered activities of enzymes involved in fatty acid metabolism have also been noted in a number of studies, signifying a possible biochemical modus operandi for anti-obesity effects in animals fed CLA (Ide, 2005). Previous trials have shown that CLA may have beneficial effects in rainbow trout culture and can be supplemented to diets without any major deleterious effects (Figueiredo-Silva et al., 2005; Bandarra et al., 2006; Valente et al., 2007). However, these studies had used fish of $5 \mathrm{~g}$ and $97 \mathrm{~g}$, far smaller than market size fish. It would

therefore be useful to elucidate whether dietary CLA could elicit more positive results in larger rainbow trout of commercial size and weight. 
TTA belongs to the family of 3-thia fatty acids, which have been studied as a dietary supplement in mammals, but much less so in other vertebrates (Skrede et al., 1997). Structurally, TTA is a 16 carbon saturated fatty acid that contains a sulphur atom at the third position from the carboxyl moiety. In mammals, TTA is a peroxisome proliferator (Berge et al., 2002) has been shown to reduce body fat in rats (Madsen et al., 2002), and can affect various aspects of mammalian lipid metabolism (Berge et al., 1989; Aarsland et al., 1989; Asiedu et al., 1993; Skrede and Bremer, 1993). Recently, dietary TTA was shown to alter the expression of a number of hepatic genes involved in lipid metabolism in Atlantic salmon (Kleveland et al., 2006). However, the authors also reported unexpectedly high mortalities in salmon fed TTA, which was not a feature of earlier trials with TTA in mammals (Berge et al., 2002).

Here we report the influence of CLA and, for the first time, TTA, on growth and lipid composition and metabolism in market-size rainbow trout grown in seawater. Trout of almost $440 \mathrm{~g}$ were fed for eight weeks on commercial formulated fish meal and fish oil based diets containing either $0.5 \%$ or $1 \%$ CLA, or $0.5 \%$ TTA and growth, feed efficiency, tissue lipid content, class and fatty acid compositions determined, along with activities of HUFA synthesis and key enzymes of fatty acid oxidation, and the expression of associated genes.

\section{Materials and methods}

\subsection{Diets and Animals}

The dietary trial was performed at BioMar Forsøgs Station, Hirtshals, Denmark, between March and May 2006. Stock, unpigmented rainbow trout (Skinnerup, Moeldrup, Denmark) acclimated to $20 \mathrm{ppt}$ salinity, were randomly distributed between twelve indoor, round tanks of $1 \mathrm{~m}^{3}$ volume $(1.72 \mathrm{~m}$ diameter). The initial stocking density was 25 fish of average weight $437 \pm 56 \mathrm{~g}(<13 \% \mathrm{CV})$ per tank $\left(\sim 10.5 \mathrm{~kg} / \mathrm{m}^{3}\right)$. Water temperature was maintained at $15.5 \pm 0.2{ }^{\circ} \mathrm{C}$ throughout the trial, with a light regime of 14L:10D. Four experimental diets were fed to triplicate tanks for 55 days, with the feeding regime based on restricted feeding at $100 \%$ of BioMar recommended feeding tables. The calculated feed ration was offered to the fish for $8 \mathrm{hr}$ each day using automatic individual belt feeding units. In order to facilitate accurate calculations of feed intake and FCR, feed waste was collected daily via a lift-up system. The experimental diets were formulated to satisfy the nutritional requirements of salmonid fish (National Research Council, 1993), and were formulated and manufactured by BioMar A/S, Brande, Denmark (Table 1). Moisture, oil, protein and ash contents of diets were determined by standard methods (AOAC, 2000). The isonitrogenous diets were based on fish meal and standard 
Northern hemisphere fish oil with CLA and TTA added to 0, 0.5 and 1\% (CLA), and 0.5\% (TTA) as percentages of total diet. Diets were identical in formulation other than fatty acid composition with CLA (LUTA-CLA ${ }^{\mathrm{TM}} 60$, containing 60\% CLA methyl esters as a 50:50 mixture of c9, $\mathrm{t} 11$ and $\mathrm{t} 10$, c12 isomers; BASF AG, Ludwigshafen, Germany) and TTA (gifted by Dr Rolf Berge, Thia Medica A.S., Bergen, Norway) balanced by fish oil of Northern hemisphere origin. The fatty acid compositions of the diets are presented in Table 2.

\subsection{Sampling protocols}

At the initiation and termination of the trial, all the fish in each tank were anaesthetised with benzocaine $(50 \mathrm{mg} / \mathrm{L})$, weighed and fork length measured individually. At the end of the trial 23 fish per tank were killed by percussion, eviscerated and right-hand fillets removed for $\alpha$-colour measurement by Minolta in triplicate along each fillet. Eight fish per tank (24 per dietary treatment) were sampled for biometric parameters (hepato-, and viscero-somatic indices). Liver and white (fast) and red (slow) muscle samples from the Flesh Quality Cut (FQC - epaxial myotomes anterior to the first dorsal fin ray) were taken from eight fish per tank and immediately frozen on dry ice for biochemical and RNA analyses. All samples were subsequently stored at $-80{ }^{\circ} \mathrm{C}$ prior to analyses.

\subsection{Lipid analyses}

Liver and skinned and deboned flesh samples, each consisting of three fish, were homogenized into pooled "pates". Total lipid was extracted from diets or $1 \mathrm{~g}$ portions of tissue pates by homogenizing in 20 volumes of chloroform/methanol $(2: 1, \mathrm{v} / \mathrm{v})$ in an Ultra-Turrax tissue disrupter (Fisher Scientific, Loughborough, U.K.). Total lipid was prepared according to the method of Folch et al. (1957) and lipid content determined gravimetrically as described previously (Kennedy et al., 2005). Tissue lipid class compositions were determined by single-dimension double-development high-performance thin-layer chromatography (HPTLC) and densitometry using a Camag 3 TLC Scanner (Camag, Muttenz, Switzerland) and winCATS software as described in Kennedy et al. (2005). Fatty acid methyl esters (FAME) from diets and tissue total lipid were prepared by acid-catalyzed transesterification of total lipid using 1\% concentrated sulphuric acid in methanol similar to the method of Christie (1993) except

that the reaction was performed at $80{ }^{\circ} \mathrm{C}$ for $3 \mathrm{~h}$. Extraction and purification of FAME was performed as described by Tocher and Harvie (1988). FAME were separated and quantified by gas-liquid chromatography (Carlo Erba Vega 8160, Milan, Italy) using a 30m x $0.32 \mathrm{~mm}$ i.d. capillary column 
(CP Wax 52CB, Chrompak, London, U.K.) and on-column injection. Hydrogen was used as carrier gas and temperature programming was from $50^{\circ} \mathrm{C}$ to $150^{\circ} \mathrm{C}$ at $40^{\circ} \mathrm{C} \mathrm{min}$ and then to $230^{\circ} \mathrm{C}$ at $2.0^{\circ} \mathrm{C} \mathrm{min}$. Methyl esters were identified and quantified as described previously (Kennedy et al., 2005).

2.4. Assay of carnitine palmitoylacyltransferase I (CPT-I), acylCoA oxidase (ACO), and highly unsaturated fatty acid (HUFA) synthesis

Liver, red and white muscle were weighed, diced and homogenized to $20 \%$ (w/v) in $0.25 \mathrm{M}$ sucrose in $10 \mathrm{mM}$ N-2-hydroxyethylpiperazine-N'-2-ethanesulfonic acid (HEPES) buffer and $1 \mathrm{mM}$ EDTA, pH 7.4. The homogenates were centrifuged at $1880 \mathrm{x} \mathrm{g}$ for $10 \mathrm{~min}$ at $4^{\circ} \mathrm{C}$, the floating fat layer aspirated and the post-nuclear fractions collected, $100 \mu \mathrm{l}$ taken for protein determination according to Lowry et al. (1957) after incubation with $400 \mu \mathrm{l}$ of $0.25 \%(\mathrm{w} / \mathrm{v}) \mathrm{SDS} / 1 \mathrm{M} \mathrm{NaOH}$ for $45 \mathrm{~min}$ at $60^{\circ} \mathrm{C}$, and portions used immediately for determination of enzyme activities. CPT-I activity was estimated by determining the production of palmitoyl $\left[{ }^{3} \mathrm{H}\right]$ carnitine from palmitoyl CoA and $\left[{ }^{3} \mathrm{H}\right]$ carnitine essentially as described by Saggerson and Carpenter (1986). ACO activity was measured by a spectrophotometric assay based on the determination of hydrogen peroxide production coupled to the oxidation of leucodichlorofluorescein (DCF) in a reaction catalyzed by exogenous peroxidase (Small et al., 1985). For HUFA synthesis, microsomes were prepared from the liver homogenate and fatty acyl desaturation and elongation determined using $\left[1-{ }^{14} \mathrm{C}\right] 18: 3 \mathrm{n}-3$ as substrate as described in detail in Kennedy et al. (2006).

\section{5. $R N A$ extraction and real-time quantitative-polymerase chain reaction ( $Q-P C R)$.}

Total RNA from liver, red and white muscles was isolated, DNase treated and reverse transcribed into cDNA as described previously (Kennedy et al., 2006). PCR primers were designed according to the trout cDNA sequences for CPT-I (accession no. AF327058), fatty acyl $\Delta 6$ desaturase (accession no. AF301910) and fatty acyl elongase (accession no. AY605100). Primer sequences and PCR product sizes are given Table 3, and all amplicons were subjected to agarose gel electrophoresis in order to confirm product size. Amplification of cDNA samples was carried out using the QuantiTect ${ }^{\circledR}$ SYBR Green PCR Kit (Qiagen, Crawley, UK) with the following conditions: $15 \mathrm{~min}$ at $95{ }^{\circ} \mathrm{C}$ to activate the HotStarTaq DNA polymerase, followed by 45 cycles of $15 \mathrm{~s}$ at $95{ }^{\circ} \mathrm{C}, 15 \mathrm{~s}$ at $56{ }^{\circ} \mathrm{C}$ and $30 \mathrm{~s}$ at $72{ }^{\circ} \mathrm{C}$, followed by product melting to check purity of PCR product. Thermal cycling and fluorescence detection were conducted using the Rotor-Gene 3000 system (Corbett Research, Cambridge, UK). Three reference genes, elongation factor-1 $\alpha(\mathrm{EF} 1 \alpha), \beta$-actin and glyceraldehyde 3-phosphate 
dehydrogenase (GAPDH), were used to normalise the expression data. The suitability of all three reference genes was determined via pair-wise correlation analysis using the BestKeeper ${ }^{\odot}$ software (Pfaffl et al., 2004). Sample specific PCR efficiency (E) was determined using comparative quantitation analysis as part of the Rotor-Gene software. The data were subjected to a pair-wise fixed reallocation randomization test $\left.{ }^{(}\right)$(10000 randomisations) in order to determine significance between treatments as facilitated by Relative Expression Software Tool - Rotor-Gene (REST-RG ${ }^{\odot}$ - version 3) (Pfaffl, et al., 2002).

\subsection{Materials}

$\left[1-{ }^{14} \mathrm{C}\right]$ Palmitoyl CoA $(50-55 \mathrm{mCi} / \mathrm{mmol})$ and $\left[\right.$ methyl $\left.-{ }^{3} \mathrm{H}\right]$ L-carnitine hydrochloride $(60-86$ $\mathrm{Ci} / \mathrm{mmol}$ ) were obtained from GE Healthcare Bio-Sciences (Little Chalfont, Bucks, U.K.), and [1$\left.{ }^{14} \mathrm{C}\right] 18: 3 \mathrm{n}-3$ (50-55 mCi/mmol) was obtained from NEN (Perkin Elmer LAS (UK) Ltd., Beaconsfield, U.K.). Aminotriazole, BHT, carnitine, coenzyme A, EDTA, FAF-BSA, HEPES, horseradish peroxidase, leuco-DCF, malate, N-acetylcysteine, NADH, NADP, palmitoyl-CoA, and TriReagent were obtained from Sigma Chemical Co. (Poole, U.K.). TLC (20 cm x $20 \mathrm{~cm}$ x $0.25 \mathrm{~mm}$ ) and HPTLC $(10 \mathrm{~cm} \times 10 \mathrm{~cm} \times 0.15 \mathrm{~mm})$ plates, precoated with silica gel 60 (without fluorescent indicator) were obtained from Merck (Darmstadt, Germany). All solvents were HPLC grade and were obtained from Fisher Scientific UK, Loughborough, England.

\subsection{Statistical analysis}

All data are presented as means $\pm \mathrm{SD}$ (n value as stated). Percentage data and data which were identified as non-homogeneous (Bartlett's test) were subjected to arcsine transformation before analysis. Other than for gene expression (see above), the effects of dietary CLA and TTA were determined by one-way analysis of variance (ANOVA) with Tukey's post-tests to determine significance of differences due to functional fatty acids. Differences were regarded as significant when $\mathrm{P}<0.05$ (Zar, 1999).

\section{Results}

\subsection{Diet compositions}


The control fish oil diet contained around 43\% total polyunsaturated fatty acids (PUFA), including 15\% eicosapentaenoic acid (20:5n-3; EPA), 14\% docosahexaenoic acid (22:6n-3; DHA) and almost 4\% 18:2n-6, 33\% total saturates, mainly $16: 0$, and $24 \%$ total monoenes, mainly $18: 1 \mathrm{n}-9$ and 16:1n-7 (Table 2). Inclusion of CLA in the diets resulted in levels of total CLA of $1.8 \%$ and $4.0 \%$ of total fatty acids at the 0.5 and $1 \%$ inclusion levels, respectively, and inclusion of $0.5 \%$ TTA resulted in TTA at a level of $1.9 \%$ of total fatty acids in the diet.

\subsection{Growth and biometry}

There were no mortalities during the dietary trial. Growth of the trout was not affected by either CLA or TTA, with neither having any significant effect on final weights, SGRs, or feed efficiency (FCR) (Table 4). Similarly, condition factor $(\mathrm{K})$, yield, as measured by gutted weight, and fillet colour ( $\alpha$ value) were unaffected by dietary treatment. There was a trend for lower viscero-somatic index (VSI) in fish fed CLA that was not statistically significant and HSI was not affected by either functional fatty acid (Table 4).

\subsection{Lipid contents and classes of liver and flesh}

The total lipid content of the trout livers was significantly lower in fish fed CLA, but not TTA, compared to fish fed fish oil alone (Table 5). Neutral lipids accounted for around $60 \%$ of liver total lipid and there were no significant effects of diet. Dietary CLA and TTA had no effect on flesh lipid contents, which varied between 7.2 and $8.2 \%$ of wet weight, or on the proportions of polar and neutral lipids (Table 5).

\subsection{Fatty acid compositions of liver and flesh}

Dietary CLA and TTA were both incorporated into tissue lipids but proportions of CLA and TTA were higher in flesh than in liver. Thus, CLA accounted for 0.6 and $1.1 \%$ of total fatty acids in livers of fish fed that fatty acid at 0.5 and $1 \%$ of diet, respectively, and TTA accounted for $0.9 \%$ of liver fatty acids in fish fed $0.5 \%$ TTA (Table 6). In flesh, the proportion of CLA reached 1.1 and $1.6 \%$ of total fatty acids at the 0.5 and $1 \%$ inclusion levels, and TTA accumulated to $1.2 \%$ of flesh fatty acids in TTA-fed fish (Table 7). The proportions of total PUFA, total n-3PUFA and arachidonic acid (AA, 20:4n-6) in liver were increased in fish fed both CLA and TTA (Table 6). The numerical values of 20:5n-3 and 
22:6n-3 in liver were consistently higher in fish fed CLA and TTA, but this only reached statistical significance with 20:5n-3 in fish fed 1\% CLA. Total saturated fatty acids and 18:0 were increased by CLA and total monoenes, particularly 18:1n-9 and 16:1n-7, were reduced in livers of fish fed both CLA and TTA. Dietary CLA and TTA had no effect on the proportions of n-3 or n-6 PUFA in trout flesh, but CLA resulted in increased percentages of 18:0 and decreased percentages of 18:1n-9 (Table 7).

3.5. Carnitine palmitoyltransferase-I (CPT-I) and acyl CoA oxidase (ACO) activities in liver, red and white muscle and HUFA synthesis in liver microsomes

Dietary TTA significantly increased the activities of CPT-I (Fig.1) and ACO (Fig.2) in liver and red muscle compared to the activity in fish fed fish oil alone. There was a trend for dietary CLA to increase ACO in liver and red muscle, but this effect was only significant in red muscle in fish fed the higher level of CLA (Fig.2). CPT-I activity was not affected by CLA in any of the three tissues, and there were no dietary effects of either supplemented fatty acid on CPT-I and ACO activities in white muscle. Neither CLA nor TTA had any affect on the overall flux through the HUFA synthesis pathway as measured by summing all the desaturated products of 18:3n-3. However, both CLA and TTA increased the amount of radioactivity from labelled 18:3n-3 that was recovered in the hexaene fraction, significantly so in the case of TTA and the higher CLA level (Fig.3).

3.6. Expression of carnitine palmitoyltransferase I (CPT-I) in liver, red and white muscle and fatty acyl desaturase and elongase in liver

There was a clear trend for CPT-I expression to be increased by $0.5 \%$ CLA and TTA in all tissues, but the increased expression was only significant in white muscle with all dietary treatments compared to fish fed fish oil (Fig.4). The expression of fatty acyl $\Delta 6$ desaturase was significantly lower in fish fed CLA and TTA compared to fish fed fish oil alone, whereas the expression of PUFA elongase was increased by dietary CLA (Fig. 5).

\section{Discussion}

We tested the hypotheses that CLA and/or TTA would have beneficial effects on the nutritional quality of rainbow trout through decreased lipid content of flesh, and increased levels of beneficial fatty acids including accumulation of CLA or TTA. The results showed that the hypotheses were only partly 
proved. CLA or TTA accumulated in flesh, which may be beneficial to the human consumer if indeed these bioactive fatty acids are beneficial in human diets. There is evidence that this may be the case with CLA (Riserus et al., 2001; Terpstra 2004; Wahle et al., 2004), but TTA is still largely untested in humans (Berge et al., 2002), although two recent studies suggest it may have lipid-lowering and antiinflammatory effects (Aukrust et al., 2003; Fredriksen et al., 2004). These issues of human nutrition are, of course, out with the scope of the present study. However, it appears that fish such as trout could be a convenient and consumer-friendly route for the delivery of bioactive or functional fatty acids in the human diet. The fatty acids can be easily incorporated into fish diets, the flesh accumulates CLA or TTA to a relatively greater extent than liver and, when combined with the relatively high flesh lipid content, means trout can deliver a reasonable dose of the bioactive fatty acids. However, the levels of CLA accumulated in flesh in this trial with trout were lower than the levels obtained in previous trials with striped bass (Twibell et al., 2000), salmon (Berge et al., 2004; Kennedy et al., 2005), trout (Valente et al., 2007) and sea bass (Valente et al., 2007) fed CLA at an equivalent inclusion level. This is consistent with the fish used in these earlier trials being smaller than those used here, as the kinetics of fatty acid composition changes will be more rapid in smaller fish. It is likely that higher levels of CLA and TTA could be achieved in larger fish with feeding periods longer than the 8 wks used in the present study.

Importantly, the accumulation of CLA or TTA did not significantly affect the levels of the n-3HUFA in flesh and therefore there was no effect on flesh fatty acid compositions that could be considered detrimental or likely to compromise the established nutritional benefit of fish for the human consumer. Indeed, it was noteworthy that one of the metabolic effects of the dietary bioactive fatty acids was the increased level of radioactivity recovered in the hexaene fraction in the HUFA synthesis assay. The hexaene fraction represented less than $10 \%$ of the total radioactivity recovered in desaturated products and could only contain 24:6n-3 as this was a microsomal assay, and peroxisomes are required for the conversion of 24:6n-3 to DHA in trout (Buzzi et al., 1997). Even so, the liver fatty acid compositions showed a definite trend of increased proportions of DHA that was, at least, consistent with the fact that CLA and TTA may have a stimulatory effect on DHA synthesis. Previously, dietary CLA increased DHA in salmon fry (Berge et al., 2004), and dietary TTA significantly increased the percentage of DHA, and decreased the proportion of EPA, in flesh of cod (Kennedy et al., 2007). In contrast, CLA did not increase biosynthesis of DHA from 18:3n-3 in humans (Attar-Bashi et al., 2007). In the present study, total HUFA synthesis, as measured by the sum of all desaturated products recovered, was low in all dietary treatments, as expected in trout (Buzzi et al., 1996), and fish in general (Tocher 2003), fed essentially fish oil diets, and there was no effect of CLA or TTA on overall HUFA synthesis. Thus, the 
effects of CLA and TTA were specifically to increase the proportion of the products of the pathway recovered as hexaenes rather than an increase in the overall activity of the HUFA synthesis pathway. Dietary CLA had no effect on the HUFA synthesis pathway in salmon fed diets with similar oil content to the diets in the present trial and, consistent with this, 1\% CLA had no effect on fatty acid desaturase expression (Kennedy et al., 2006). Therefore, it was surprising that the expression of the trout desaturase gene in the present trial was greatly reduced by both CLA and TTA without affecting overall HUFA synthesis. The generally low level of HUFA synthesis, perhaps combined with a compensatory increase in PUFA elongase expression, may have mitigated the effect of decreased desaturase expression. The suppression of desaturase expression by CLA is not without precedent, as CLA has been shown to suppress PUFA desaturase and elongase in mammalian cell systems (Chuang et al., 2001a,b; Eder et al., 2002). The lack of a direct correlation between desaturase expression and HUFA synthesis may indicate that the effects of CLA or TTA were mediated through post-translational modification rather than transcriptional regulation.

CLA had very clear effects on the 18:0/18:1n-9 ratio with greatly increased 18:0, and decreased levels of 18:1n-9, in liver and, to a lesser extent, flesh lipids. Similar observations have been made previously in striped bass (Twibell et al., 2000), yellow perch (Twibell et al., 2001), salmon (Berge et al., 2004; Kennedy et al., 2006), cod (Kennedy et al., 2007) and sea bass (Valente et al., 2007). In addition, dietary CLA increased the proportions of 18:0 and decreased percentages of 18:1 in liver, muscle and viscera of rainbow trout juveniles (Bandarra et al., 2006). These data are entirely consistent with CLA inhibiting stearoyl CoA desaturase (SCD) in trout and fish in general. In contrast, the data in the present study have shown that TTA has only a moderate on SCD in trout. The percentages of 18:0 and 18:1n-9 in liver were only slightly altered and there was no effect in flesh. Previously, dietary TTA was shown to have no major effects on 18:0/18:1n-9 levels in salmon liver, gill or heart lipids (Moya-Falcon et al., 2004), and cod liver or flesh lipids (Kennedy et al., 2007). Similarly, TTA had no effect on 18:0/18:1n-9 levels in hepatocytes from salmon fed $0.6 \%$ TTA or in hepatocytes incubated with $0.8 \mathrm{mM}$ TTA (Moya-Falcon et al., 2006). In contrast, TTA has been shown to up-regulate SCD in mammals (Madsen et al., 1997).

Dietary CLA can have beneficial effects on body composition in mammals, decreasing body fat and increasing lean body mass in mice, rats and pigs (Wang and Jones, 2004). Similarly, TTA has been shown to prevent high fat diet induced adiposity in mammals (Madsen et al., 2002). However, there was no evidence that dietary CLA or TTA, at the levels used, could exert a beneficial effect on flesh lipid content in trout. In two previous trials on salmonids, total lipid content of flesh in salmon and trout was not reduced by dietary CLA, although these trials used smaller animals compared to the 
present trial, around $87 \mathrm{~g}$ for the salmon smolts and only $5 \mathrm{~g}$ for the trout (Kennedy et al., 2005; Bandarra et al., 2006). We reasoned that perhaps salmonids in those size ranges were not ideal for investigating bioactive fatty acids, which have effects on lipid oxidation and deposition, as fish at that stage of development will not be depositing large amounts of lipid in the flesh during the trials' periods. Hence the reason larger fish were used, growing from approximately $400 \mathrm{~g}$ to almost $800 \mathrm{~g}$, and for performing the trial in seawater in the present study. Although, due to the larger size of the fish, whole body proximate composition was not measured in the present trial, there was no suggestion from any of the biometric or tissue lipid analyses data to suggest a lipid reduction in the large trout by CLA or TTA. It has been consistently shown in previous trials that CLA had no significant effect on whole body proximate composition in fish (Twibell and Wilson, 2003; Berge et al., 2004; Figueirdo-Silva et al., 2005; Kennedy et al., 2005, 2007; Valente et al., 2007). Dietary TTA at 0.6\%, but not 0.3\%, reduced carcass fat in salmon (86g) (Moya-Falcon et al., 2004), and 0.5\% TTA had no effect on cod proximate composition (Kennedy et al., 2007). Furthermore, the lipid content data in the present trial suggest no redistribution of fat between liver and flesh, and the unchanged HSI, VSI and K values are consistent with no major changes in fat distribution in general. Therefore, no significant effects of CLA and TTA on lipid deposition were observed, despite using larger fish. Thus, the evidence is not supportive of CLA or TTA having any commercially important effects on lipid deposition in salmonids.

In contrast to flesh, liver lipid was lowered by dietary CLA in the present study, and similar results were obtained previously in striped bass (Twibell et al., 2000), and yellow perch (Twibell et al., 2001) and $97 \mathrm{~g}$ trout (Valente et al., 2007). Feeding CLA also reduced liver triacylglycerol levels in rats (Rahman et al., 2002) and, in rodents, studies have suggested that CLA increased fatty acid oxidation via an increase in CPT-I activity (Rahman et al., 2001; Degrace et al., 2004). However, neither CPT-I nor ACO (key enzymes of mitochondrial and peroxisomal $\beta$-oxidation, respectively) were increased in liver by dietary CLA, and CPT-I expression in liver was also unaffected by either bioactive fatty acid. In contrast, TTA increased both CPT-I and ACO in trout liver, but this was not reflected in lower liver lipid, similar results to those obtained previously in cod (Kennedy et al., 2007). Therefore, the mechanism of decreased lipid content in liver of fish fed CLA is unclear as it does not appear to be related to fatty acid oxidation. This dissociation between tissue lipid levels and indicators of fatty acid oxidation was also observed in muscle tissue as TTA increased CPT-I and ACO in red muscle and high CLA increased red muscle ACO. This can perhaps be explained, however, as red muscle constitutes only a small proportion of flesh and so metabolic changes in it are not so likely to result in changes in overall flesh composition. In white muscle, which constitutes the bulk of flesh, CPT-I and ACO 
activities were unaffected by CLA and TTA. Considering the lack of effect CPT-I activity, the increased CPT-I expression in white muscle of fish fed either CLA or TTA was a contradiction. Disparity between CPT-I activities and fatty acid oxidation in hamsters fed CLA has also been observed, and it was suggested that this may be due to increased sensitivity of CPT-I to malonyl-CoA in animals fed CLA (Bouthegourd et al., 2002). A similar mechanism could account for the lack association between CPT-I expression and activity in the present trial.

CLA has been studied to a far greater extent than TTA and so more potential effects are known. For instance, CLA may have effects on growth performance in mammals as some studies have suggested that it can enhance growth and feed efficiency in young rodents (Pariza et al., 2001). However, these effects on growth have not been replicated in previous trials on a variety of fish species (Twibell et al., 2001; Twibell and Wilson, 2003; Berge et al., 2004; Yasmin et al., 2004; Kennedy et al., 2005, 2007; Manning et al., 2006), including small rainbow trout (Figuierdo-Silva et al., 2005; Valente et al., 2007). This trial with market size fish also showed no effect on growth at all. Final weight, SGRs and FCRs were all unaffected by CLA or TTA at the levels tested. It was particularly noteworthy that there was no detrimental effect on growth or mortality in trout fed $0.5 \%$ TTA. Previously, significant depressed growth and increased mortality was reported in salmon smolts fed 0.6\% TTA (Moya-Falcon et al., 2004), and a slight increase in mortality in cod fed 0.5\% TTA (Kennedy et al., 2007).

In conclusion, the results of the present study only partly support the hypotheses that we set out to test. Thus CLA or TTA did not beneficially alter the lipid content of the flesh in commercial size rainbow trout grown in seawater. However, trout preferentially accumulated CLA or TTA in the flesh compared to liver, with no detrimental effect on flesh n-3 HUFA levels. Therefore, if CLA or TTA are proved to be beneficial in the human diet, trout may be a convenient and consumer-friendly source of these fatty acids, thus enhancing the nutritional quality through provision of n-3 HUFA and bioactive fatty acids.

\section{Acknowledgements}

This work and SRK was supported by a Biotechnology and Biological Science Research Council (BBSRC) CASE studentship award (BioMar Ltd., Grangemouth, Scotland). We are grateful to Dr. D. Feuerstein (BASF, Germany) for the provision of the commercial CLA and for financial assistance.

\section{References}


Aarsland, A., Aarsaether, N., Bremer, J., Berge, R.K., 1989. Alkylthioacetic acids (3-thia fatty acids) as non- $\beta$-oxidizable fatty acid analogues: a new group of hypolipidemic drugs. III. Dissociation of cholesterol- and triglyceride-lowering effects and the induction of peroxisomal $\beta$-oxidation. J. Lipid Res. 30, 1711-1718.

AOAC, 2000. Official methods of analysis. Association of official Analytical Chemists, Gaithersburg, Maryland, USA.

Asiedu, D.K., Skorve, J., Willumsen, N., Demoz, A., Berge, R.K., 1993. Early effects on mitochondrial and peroxisomal $\beta$-oxidation by the hypolipidemic 3-thia FAs in rat liver. Biochim. Biophys. Acta 1166, 73-76,

Attar-Bashi, N.M., Weisinger, R.S., Begg, D.P., Li, D., Sinclair, A.J., 2007. Failure of conjugated linoleic acid supplementation to enhance biosynthesis of docosahexaenoic acid from $\alpha$-linolenic acid in healthy human volunteers. Prostaglandins Leukotrienes Essent. Fatty acids 76, 121-130.

Aukrust, P., Wergedahl, H., Muller, F., Ueland, T., Dyroy, E., Damas, J.K., Froland, S.S., Berge, R.K., 2003. Immunomodulating effects of 3-thia fatty acids in activated peripheral blood mononuclear cells. Eur. J. Clin. Invest. 33, 426-433.

Bandarra, N.M., Nunes, M.L., Andrade, A.M., Prates, J.A.M., Pereira, S., Monteiro, M., Rema, P, Valente, L.M.P., 2006. Effect of conjugated linoleic acid on muscle, liver and visceral lipid deposition in rainbow trout juveniles (Oncorhynchus mykiss). Aquaculture 254, 496-505.

Bell, J.G., 1998. Current aspects of lipid nutrition in fish farming. In: Black, K.D., Pickering, A.D. (Eds.), Biology of Farmed Fish. Sheffield Academic, Sheffield, pp. 114-145.

Berge, G.M., Ruyter, B., Asgard, T., 2004. Conjugated linoleic acid in diets for juvenile Atlantic salmon (Salmo salar); effects on fish performance, proximate composition, fatty acid and mineral content. Aquaculture 237, 365-380.

Berge, R.K., Aarsland, A., Kryvi, H., Bremer, J., Aarsaether, N., 1989. Alkylthioacetic acids (3-thia FAs) - a new group of non-beta-oxidizable peroxisome-inducing fatty acid analogues: II. Doseresponse studies on hepatic peroxisomal- and mitochondrial changes and long-term fatty acid metabolizing enzymes in rat. Biochem. Pharmacol. 38, 3969-3979.

Berge, R.K., Skorve, J., Tronstad, K.J., Berge, K., Gudbrandsen, O.A., Grav, H., 2002. Metabolic effects of thia fatty acids. Curr. Opin. Lipidol. 13, 295-304. 
Bouthegourd, J.C., Even, P.C., Gripois, D., Toffon, B., Blouquit, M.F., Roseau, S., Lutton, C., Tome, D., Martin, J.C., 2002. A CLA mixture prevents body triglyceride accumulation without affecting energy expenditure in Syrian hamsters. J. Nutr. 132, 2682-2689.

Buzzi, M., Henderson, R.J., Sargent, J.R., 1996. The desaturation and elongation of linolenic acid and eicosapentaenoic acid by hepatocytes and liver microsomes from rainbow trout (Oncorhyncus mykiss) fed diets containing fish oil or olive oil. Biochim. Biophys. Acta, 1299, 235-244.

Buzzi, M., Henderson, R.J., Sargent, J.R., 1997. Biosynthesis of docosahexaenoic acid in trout hepatocytes proceeds via 24-carbon intermediates. Comp. Biochem. Physiol. 116, 263-267.

Choi, Y., Park, Y., Pariza, M.W., Ntambi, J,M., 2001. Regulation of stearoyl-CoA desaturase activity by the trans-10,cis-12 isomer of conjugated linoleic acid in HepG2 cells. Biochem Biophy. Res. Commun. 284, 689-693.

Choi, Y., Park, Y., Storkson, J.M., Pariza, M.W., Ntambi, J,M., 2002. Inhibition of stearoyl-CoA desaturase activity by the cis-9,trans-11 isomer and the trans-10,cis-12 isomer of conjugated linoleic acid in MDA-MB-231 and MCF-7 human breast cancer cells. Biochem Biophy. Res. Commun. 294, 785-790.

Christie W.W. 1993. Preparation of derivatives of fatty acids for chromatographic analysis. In: Christie, W.W. (Ed.), Advances in Lipid Methodology - Two. The Oily Press, Dundee. pp.69-111.

Chuang, L.T., Leonard, A.E., Liu, J.W., Mukerji, P., Bray, T.M., Huang, Y.S., 2001a. Inhibitory effect of conjugated linoleic acid on linoleic acid elongation in transformed yeast with human elongase. Lipids 36, 1099-1103.

Chuang, L.T., Thurmond, J.M., Liu, J.W., Kirchner, S.J., Mukerji, P., Bray, T.M., Huang, Y.S., 2001 b. Effect of conjugated linoleic acid on fungal $\Delta 6$-desaturase activity in a transformed yeast system. Lipids 36, 139-143. 
Degrace, P., Demizieux, L., Gresti, J., Chardigny, J.M., Sebedio, J.L., Clouet, P., 2004. Hepatic steatosis is not due to impaired fatty acid oxidation capacities in C57BL/6J mice fed the conjugated trans-10,cis-12-isomer of linoleic acid. J. Nutr. 134, 861-867.

Eder, K., Slomma, N., Becker, K., 2002. Trans-10,cis-12 conjugated linoleic acid suppresses the desaturation of linoleic and $\alpha$-linolenic acids in HepG2 cells. J. Nutr. 132, 1115-1121.

Figueiredo-Silva, A.C., Rema, P., Bandarra, N.M, Nunes, M.L, Valente, L.M.P., 2005. Effects of dietary conjugated linoleic acid on growth, nutrient utilization, body composition, and hepatic lipogenesis in rainbow trout juveniles (Oncorhynchus mykiss). Aquaculture 248, 163-172.

Folch, J., Lees, M., Sloane-Stanley, G.H., 1957. A simple method for the isolation and purification of total lipids from animal tissues. J. Biol. Chem. 226, 497-509.

Fredriksen, J., Ueland, T., Dyroy, E., Halvorsen, B., Melby, K., Melbye, L., Skalhegg, B.S., Bohov, P., Skorve, J., Berge, R.K., Aukrust, P., Froland, S.S., 2004. Lipid-lowering and anti-inflammatory effects of tetradecylthioacetic acid in HIV-infected patients on highly active antiretroviral therapy. Eur. J. Clin. Invest. 34, 709-715.

Ide, T., 2005. Interaction of fish oil and conjugated linoleic acid in affecting hepatic activity of lipogenic enzymes and gene expression in liver and adipose tissue. Diabetes 54, 412-423.

Keim, N.L., 2003. Conjugated linoleic acid and body composition. In: Sebedio, J.-L., Christie, W.W., Adlof, R. (Eds.), Advances in Conjugated Linoleic Acid Research, vol.2. AOCS Press, Champaign. pp.316-324.

Kennedy, S.R., Bickerdike, R., Berge, R.K., Porter, A.R., Tocher, D.R., 2007. Influence of dietary conjugated linoleic acid (CLA) and tetradecylthioacetic acid (TTA) on growth, lipid composition and key enzymes of fatty acid oxidation in liver and muscle of Atlantic cod (Gadus morhua L.). Aquaculture, in press.

Kennedy, S.R., Campbell, P.J., Porter, A., Tocher, D.R., 2005. Influence of dietary conjugated linoleic 
acid (CLA) on lipid and fatty acid composition in liver and flesh of Atlantic salmon (Salmo salar), Comp. Biochem. Physiol. 141B, 168-178.

Kennedy, S.R., Leaver, M.J., Campbell, P.J., Zheng, X., Dick, J.R., Tocher, D.R., 2006. Influence of dietary oil content and conjugated linoleic acid (CLA) on lipid metabolism enzyme activities and gene expression in tissues of Atlantic salmon (Salmo salar L.). Lipids 41, 423-436.

Kleveland, E.J., Ruyter, B., Vegusdal, A., Sundvold, H., Berge, R.K., Gjøen, T., 2006. Effects of 3-thia fatty acids on expression of some lipid related genes in Atlantic salmon (Salmo salar L.). Comp. Biochem. Physiol. 145B, 239-248.

Lowry, O.H., Rosebrough, N.J., Farr, A.L., Randall, R.J., 1951. Protein measurement with the folin phenol reagent, J. Biol. Chem. 193, 265-275.

Madsen, L., Froyland, L., Grav, H.J., Berge, R.K., 1997. Up-regulated $\Delta 9$-desaturase gene expression by hypolipidemic peroxisome-proliferating fatty acids results in increased oleic acid content in liver and VLDL. J. Lipid Res. 38, 554-563.

Madsen, L., Guerre-Millo, M., Flindt, E.N., Berge, K., Tronstad, K.J., Bergene, E., Sebokova, E., Rustan, A.C., Jensen, J., Mandrup, S., Kristiansen, K., Klimes, I., Staels, B., Berge, R.K., 2002. Tetradecylthioacetic acid prevents high fat diet induced adiposity and insulin resistance. J. Lipid Res. 43, 742-750.

Manning, B.B., Li, M.H., Robinson, E.H., Peterson, B.C., 2006. Enrichment of channel catfish (Ictalurus punctatus) fillets with conjugated linoleic acid and omega-3 fatty acids by dietary manipulation. Aquaculture 261, 337-342.

Moya-Falcon, C., Hvattum, E., Dyrøy, E., Skorve, J., Stefansson, S.O., Thomassen, M., Jakobsen, J.V., Berge, R.K., Ruyter, B., 2004. Effects of 3-thia fatty acids on feed intake, growth, tissue fatty acid composition, $\beta$-oxidation and $\mathrm{Na}^{+}, \mathrm{K}^{+}$-ATPase activity in Atlantic salmon. Comp. Biochem. Physiol. 139B, 657-668. 
Moya-Falcon, C., Hvattum, E., Tran, T.N., Thomassen, M.S., Skorve, J., Ruyter, B., 2004. Phospholipid molecular species, $\beta$-oxidation, desaturation and elongation of fatty acids in Atlantic salmon hepatocytes: Effects of temperature and 3-thia fatty acids. Comp. Biochem. Physiol. 145B, 68-80.

National Research Council, 1993. Nutrient Requirements of Fish, National Academic Press, Washington, DC.

Pariza, M.W., Park, Y., Cook, M.E., 2001. The biologically active isomers of conjugated linoleic acid. Prog. Lipid Res. 40, 283-298.

Pfaffl, M.W., Horgan, G.W., Dempfle, L., 2002. Relative expression software tool (REST ${ }^{\odot}$ ) for groupwise comparison and statistical analysis of relative expression results in real-time PCR. Nucleic Acids Res. 30, E36.

Pfaffl, M.W., Tichopad, A., Prgomet, C., Neuvians, P., 2004. Determination of stable housekeeping genes, differentially regulated target genes and sample integrity: BestKeeper - Excel based tool using pair-wise correlations. Biotechnol. Lett. 26, 509-515.

Rahman, S.M., Huda, M.N., Uddin, M.N., Akhteruzzaman, S., 2002. Short-term administration of conjugated linoleic acid reduces liver triglyceride concentration and phosphatidate phosphohydrolase activity in OLETF rats. J. Biochem. Mol. Biol. 35, 494-497.

Rahman, S.M., Wang, Y.M., Yotsumoto, H., Cha, .Y., Han, S.Y., Inoue, S., Yanagita, T., 2001. Effects of Conjugated linoleic acid on serum leptin concentration, body-fat accumulation, and $\beta$-oxidation of fatty acid in OLETF rats. Nutrition 17, 385-390.

Riserus, U., Berglund, L., Vessby, B., 2001. Conjugated linoleic acid (CLA) reduced abdominal adipose tissue in obese middle-aged men with signs of the metabolic syndrome: a randomised controlled trial. Internat. J. Obesity Related Metabolic Disorders 25, 1129-1135. 
Saggerson, E.D., Carpenter, C.A., 1986. Carnitine palmitoyltransferase in liver and five extrahepatic tissues in the rat. Inhibition by DL-2-bromopalmitoyl-CoA and effect of hypothyroidism. Biochem. J. 236, 137-141.

Sargent, J.R., Tocher, D.R., Bell, J.G., 2002. The lipids. In: Halver, J.E., Hardy, R.W. (Eds.), Fish Nutrition, $3^{\text {rd }}$ Edition, Academic Press, San Diego, pp 181-257.

Skrede, S., Bremer, J., 1993. Acylcarnitine formation and fatty acid oxidation in hepatocytes from rats treated with tetradecylthioacetic acid (a 3-thia fatty acid). Biochim. Biophys. Acta 1005, 296-302.

Skrede, S., Sørensen, H.N., Larsen, L.N., Steineger, H.H., Høvik, K., Spydevold, Ø.S., Horn, R., Bremer, J., 1997. Thia fatty acids, metabolism and metabolic effects. Biochim. Biophys. Acta 1344, 115-131.

Small, G.M., Burdett, K., Connock, M.J., 1985. A sensitive spectrophotometric assay for peroxisomal acyl-CoA oxidase. Biochem. J. 227, 205-210.

Smith, S.B., Hively, T.S., Cortese, G.M., Han, J.J., Chung, K.Y., Castenada, P., Gilbert, C.D., Adams, V.L., Mersmann, H.J., 2002. Conjugated linoleic acid depresses the $\Delta 9$ desaturase index and stearoyl coenzyme A desaturase enzyme activity in porcine subcutaneous adipose tissue. J. Anim. Sci. 80, 2110-2115.

Tacon, A.G.J., 2003. Global trends in aquaculture and compound aquafeed production. In: Tacon, A.G.J. (Ed.), Internatl. Aquafeed Directory and Buyer's Guide 2003, Turret RAI, Uxbridge, pp 8-23.

Terpstra, A.H., 2004. Effect of conjugated linoleic acid on body composition and plasma lipids in humans: an overview of the literature. Am. J. Clin. Nutr. 79, 352-361.

Tocher, D.R., 2003. Metabolism and functions of lipids and fatty acids in teleost fish. Rev. Fish. Sci. $11,107-184$.

Tocher, D.R., Harvie, D.G., 1988. Fatty acid compositions of the major phosphoglycerides from fish neural tissues : (n-3) and (n-6) polyunsaturated fatty acids in rainbow trout (Salmo gairdneri, L.) and cod (Gadus morhua) brains and retinas. Fish Physiol. Biochem. 5, 229-239. 
Twibell, R.G., Wilson, R.P., 2003. Effects of conjugated linoleic acids and total dietary lipid concentrations on growth responses of juvenile channel catfish, Ictalurus punctatus. Aquaculture $221,621-628$.

Twibell, R.G., Watkins, B.A., Brown, P.B., 2001. Dietary conjugated linoleic acids and lipid source alter fatty acid composition of juvenile yellow perch, Perca flavescens. J. Nutr. 131, 2322-2328.

Twibell, R.G., Watkins, B.A., Rogers, L., Brown, P.B., 2000. Effects of dietary conjugated linoleic acids on hepatic and muscle lipids in hybrid striped bass. Lipids 35, 155-161.

Valente, L.M.P., Bandarra, N.M., Figueiredo-Silva, A.C., Cordeiro, A.R., Simoes, R.M., Nunes, M.L., 2007. Influence of conjugated linoleic acid on growth, lipid composition, and hepatic lipogenesis in juveniles European sea bass (Dicentrarchus labrax). Aquaculture, in press.

Valente, L.M.P., Bandarra, N.M., Figueiredo-Silva, A.C., Rema, P., Vaz-Pires, P., Martins, S., Prates, J.A.M., Nunes, M.L., 2007. Conjugated linoleic acid in diets for large-size rainbow trout (Oncorhynchus mykiss): effects on growth, chemical composition, and sensory attributes. Brit. J. Nutr. 97, 289-297.

Wahle, K.W.J., Heys, S.D., Rotondo, D., 2004. Conjugated linoleic acids: are they beneficial or detrimental to health? Prog. Lipid res. 43, 553-587.

Wang, Y.: Jones, P.J., 2004. Dietary conjugated linoleic acid and body composition. Am. J. Clin. Nutr. 79, 1153S-1158S.

Wilson, R.P., 1989. Amino acids and proteins. In: Halver, J.E. (Ed.), Fish Nutrition, $2^{\text {nd }}$ Edition. Academic, San Diego, pp. 111-151.

Yasmin, A., Takeuchi, T., Hayashi, M., Hirota, T., Ishizuka, W., Ishida, S., 2004. Effect of conjugated linoleic and docosahexaenoic acids on growth of juvenile tilapia Oreochromis niloticus. Fisheries Sci. $70,473-481$.

Zar J.H., 1999. Biostatistical Analysis $4^{\text {th }}$ Edition; Prentice-Hall; Upper Saddle River, New Jersey. 
Legends to Figures

Fig.1. Effects of conjugated linoleic acid (CLA) or tetradecylthioacetic acid (TTA) on carnitine palmitoyltransferase-I (CPT-I) activities in tissue homogenates of liver, red and white muscle of rainbow trout. Results are presented relative to the activity in fish fed fish oil for each tissue and are means \pm SD $(n=6)$. Different letters denote significant differences between dietary treatments within each tissue. CLA1 and CLA2, fish fed 0.5\% and 1\% CLA, respectively; FO, fish fed fish oil alone; TTA, fish fed $0.5 \%$ TTA.

Fig.2. Effects of conjugated linoleic acid (CLA) or tetradecylthioacetic acid (TTA) on acyl CoA oxidase activities in tissue homogenates of liver, red and white muscle of rainbow trout. Results are presented relative to the activity in fish fed fish oil for each tissue and are means $\pm \operatorname{SD}(n=6)$. Different letters denote significant differences between dietary treatments within each tissue. CLA1 and CLA2, fish fed 0.5\% and 1\% CLA, respectively; FO, fish fed fish oil alone; TTA, fish fed 0.5\% TTA.

Fig.3. Effects of conjugated linoleic acid (CLA) or tetradecylthioacetic acid (TTA) on total $\beta$-oxidation activities in tissue homogenates of liver, red and white muscle of rainbow trout. Results are presented relative to the activity in fish fed fish oil for each tissue and are means $\pm \operatorname{SD}(n=6)$. Different letters denote significant differences between dietary treatments within each tissue. CLA1 and CLA 2, fish fed $0.5 \%$ and $1 \%$ CLA, respectively; FO, fish fed fish oil alone; TTA, fish fed $0.5 \%$ TTA.

Fig.4. Effects of conjugated linoleic acid (CLA) or tetradecylthioacetic acid (TTA) on the expression of carnitine palmitoyltransferase-I (CPT-I) in the liver, red and white muscle of rainbow trout. Genes were determined by Q-PCR and normalised relative to three housekeeping genes as described in Materials and Methods. Results are presented relative to the activity in fish fed fish oil and are means \pm SD $(n=$ 6). Different letters denote significant differences between dietary treatments. CLA1 and CLA 2, fish fed $0.5 \%$ and $1 \%$ CLA, respectively; FO, fish fed fish oil alone; TTA, fish fed $0.5 \%$ TTA.

Fig.5. Effects of conjugated linoleic acid (CLA) or tetradecylthioacetic acid (TTA) on the expression of fatty acyl $\Delta 6$ desaturase and elongase genes in liver of rainbow trout. Genes were determined by QPCR and normalised relative to three housekeeping genes as described in Materials and Methods. 
Results are presented relative to the activity in fish fed fish oil and are means \pm SD $(n=6)$. Different letters denote significant differences between dietary treatments. CLA1 and CLA 2, fish fed $0.5 \%$ and $1 \%$ CLA, respectively; FO, fish fed fish oil alone; TTA, fish fed $0.5 \%$ TTA. 
Table 1. Formulations (percentage of dry ingredients) and proximate compositions (percentage of total diet) of experimental diets

\begin{tabular}{lcccc}
\hline & FO & CLA1 & CLA2 & TTA \\
\hline Fishmeal & 41 & 41 & 41 & 41 \\
Sunflower meal & 10.7 & 10.7 & 10.7 & 10.7 \\
Wheat gluten & 10 & 10 & 10 & 10 \\
Legume seeds & 14 & 14 & 14 & 14 \\
Soya & 4 & 4 & 4 & 4 \\
Micronutrients & 0.4 & 0.4 & 0.4 & 0.4 \\
Fish oil & 22.5 & 21.7 & 20.8 & 22 \\
CLA & 0 & 0.8 & 1.7 & 0 \\
TTA & 0 & 0 & 0 & 0.5 \\
Moisture & $7.3 \pm 0.2$ & $7.5 \pm 0.1$ & $7.6 \pm 0.1$ & $7.5 \pm 0.2$ \\
Lipid & $27.7 \pm 1.1$ & $25.7 \pm 0.5$ & $24.8 \pm 0.7$ & $24.7 \pm 1.9$ \\
Protein & $43.5 \pm 0.6$ & $42.1 \pm 0.2$ & $42.6 \pm 1.1$ & $42.6 \pm 0.6$ \\
Ash & $8.4 \pm 0.3$ & $8.4 \pm 0.0$ & $8.4 \pm 0.3$ & $8.5 \pm 0.1$ \\
\hline
\end{tabular}

Results for proximate compositions are means \pm S.D. $(n=3)$. Micronutrients, includes essential amino acids (methionine and lysine), vitamins, minerals, and astaxanthin (35 mg/kg Lucantin ${ }^{\circledR}$ Pink, BASF), Biomar A/S, Brande, Denmark. FO, control diet containing fish oil alone; CLA1 and CLA2, diets supplemented with 0.5 and $1 \%$ CLA; TTA, diet supplemented with $0.5 \%$ TTA. There were no significant differences in proximate compositions between the diets. 
Table 2. Fatty acid compositions (percentage of weight) of experimental diets containing conjugated linoleic acid (CLA) and tetradecylthioacetic acid (TTA)

\begin{tabular}{|c|c|c|c|c|}
\hline & FO & CLA1 & CLA2 & TTA \\
\hline $14: 0$ & $7.8 \pm 0.2$ & $7.7 \pm 0.2$ & $7.4 \pm 0.2$ & $7.9 \pm 0.3$ \\
\hline $15: 0$ & $0.7 \pm 0.0$ & $0.7 \pm 0.0$ & $0.6 \pm 0.0$ & $0.7 \pm 0.0$ \\
\hline $16: 0$ & $20.2 \pm 0.1$ & $20.2 \pm 0.3$ & $19.6 \pm 0.4$ & $20.4 \pm 0.5$ \\
\hline $18: 0$ & $4.2 \pm 0.1$ & $4.2 \pm 0.1$ & $4.2 \pm 0.1$ & $4.2 \pm 0.1$ \\
\hline Total saturated $^{1}$ & $33.3 \pm 0.3$ & $33.1 \pm 0.6$ & $32.2 \pm 0.8$ & $33.5 \pm 0.9$ \\
\hline $16: 1 n-7$ & $8.3 \pm 0.2^{\mathrm{a}}$ & $8.1 \pm 0.0^{\mathrm{a}}$ & $7.8 \pm 0.0^{b}$ & $8.2 \pm 0.1^{\mathrm{a}}$ \\
\hline $18: \ln -9$ & $8.3 \pm 0.0^{\mathrm{c}}$ & $8.8 \pm 0.1^{\mathrm{b}}$ & $9.4 \pm 0.0^{\mathrm{a}}$ & $8.1 \pm 0.1^{\mathrm{d}}$ \\
\hline $18: 1 n-7$ & $3.2 \pm 0.1$ & $3.2 \pm 0.0$ & $3.1 \pm 0.1$ & $3.3 \pm 0.0$ \\
\hline $20: 1 n-9$ & $1.5 \pm 0.0$ & $1.4 \pm 0.0$ & $1.4 \pm 0.0$ & $1.4 \pm 0.1$ \\
\hline $22: 1 n-11$ & $1.7 \pm 0.2$ & $1.7 \pm 0.1$ & $1.7 \pm 0.0$ & $1.7 \pm 0.1$ \\
\hline $24: 1 n-9$ & $0.5 \pm 0.1$ & $0.5 \pm 0.0$ & $0.5 \pm 0.0$ & $0.5 \pm 0.0$ \\
\hline Total monoenes ${ }^{2}$ & $23.9 \pm 0.4$ & $23.9 \pm 0.3$ & $24.2 \pm 0.1$ & $23.5 \pm 0.3$ \\
\hline $\operatorname{CLA}(9 \mathrm{c}, 11 \mathrm{t})$ & $0.0 \pm 0.0^{\mathrm{c}}$ & $0.9 \pm 0.1^{\mathrm{b}}$ & $2.0 \pm 0.2^{\mathrm{a}}$ & $0.0 \pm 0.0^{\mathrm{c}}$ \\
\hline CLA $(10 t, 12 \mathrm{c})$ & $0.0 \pm 0.0^{\mathrm{c}}$ & $0.9 \pm 0.1^{\mathrm{b}}$ & $2.0 \pm 0.2^{\mathrm{a}}$ & $0.0 \pm 0.0^{\mathrm{c}}$ \\
\hline TTA & $0.0 \pm 0.0^{b}$ & $0.0 \pm 0.0^{b}$ & $0.0 \pm 0.0^{b}$ & $1.9 \pm 0.1^{\mathrm{a}}$ \\
\hline $18: 2 n-6$ & $3.7 \pm 0.1$ & $3.6 \pm 0.0$ & $3.8 \pm 0.0$ & $3.6 \pm 0.0$ \\
\hline $20: 4 n-6$ & $1.3 \pm 0.0$ & $1.2 \pm 0.0$ & $1.2 \pm 0.0$ & $1.2 \pm 0.0$ \\
\hline Total n-6 PUFA & $6.3 \pm 0.2$ & $6.0 \pm 0.1$ & $6.0 \pm 0.0$ & $5.8 \pm 0.1$ \\
\hline $18: 3 n-3$ & $1.1 \pm 0.0$ & $1.1 \pm 0.0$ & $1.0 \pm 0.0$ & $1.1 \pm 0.0$ \\
\hline $18: 4 n-3$ & $2.8 \pm 0.0$ & $2.6 \pm 0.0$ & $2.6 \pm 0.0$ & $2.7 \pm 0.0$ \\
\hline $20: 4 n-3$ & $0.9 \pm 0.1$ & $1.0 \pm 0.3$ & $0.7 \pm 0.0$ & $0.7 \pm 0.0$ \\
\hline $20: 5 n-3$ & $15.3 \pm 0.3^{\mathrm{a}}$ & $14.9 \pm 0.1^{\mathrm{ab}}$ & $14.4 \pm 0.1^{b}$ & $15.2 \pm 0.2^{\mathrm{a}}$ \\
\hline $22: 5 n-3$ & $1.8 \pm 0.0$ & $1.7 \pm 0.0$ & $1.6 \pm 0.0$ & $1.7 \pm 0.0$ \\
\hline $22: 6 n-3$ & $14.2 \pm 0.2^{\mathrm{a}}$ & $13.6 \pm 0.2^{\mathrm{bc}}$ & $13.2 \pm 0.2^{\mathrm{c}}$ & $13.8 \pm 0.3^{\mathrm{ab}}$ \\
\hline Total n-3 PUFA & $36.4 \pm 0.3^{a}$ & $35.1 \pm 0.1^{\mathrm{b}}$ & $33.7 \pm 0.3^{c}$ & $35.3 \pm 0.5^{b}$ \\
\hline Total PUFA & $42.7 \pm 0.3^{\mathrm{a}}$ & $41.1 \pm 0.1^{b}$ & $39.7 \pm 0.3^{c}$ & $41.1 \pm 0.6^{b}$ \\
\hline$n-3 / n-6$ & $5.8 \pm 0.2^{b c}$ & $5.9 \pm 0.1 \mathrm{ab}$ & $5.6 \pm 0.0^{c}$ & $6.1 \pm 0.0^{\mathrm{a}}$ \\
\hline
\end{tabular}

Values are means $\pm \mathrm{SD}(\mathrm{n}=3)$. An SD of 0.0 denotes a value of $<0.05$. Superscript letters denote significant differences between diets as determined by ANOVA as described in the Materials and Methods. PUFA, polyunsaturated fatty acids.

${ }^{1}$, includes 20:0, present in some samples at up to $0.3 \%$.

${ }^{2}$, includes $20: 1 \mathrm{n}-7$ present in some samples at up to $0.3 \%$.

${ }^{3}$, includes $18: 3 n-6,20: 2 n-6,20: 3 n-6$ and $22: 4 n-6$ present at up $0.4 \%$.

${ }^{4}$, includes $20: 3 n-3$ present at up to $0.2 \%$. 
Table 3. Sequences of primers and PCR product sizes.

\begin{tabular}{lcccc}
\hline Gene & Accession No. & Primer & Sequence & Product size $(\mathrm{bp})$ \\
\hline CPT-I & AF327058 & Forward & GCGCTATTCGACCAAAAAGA & 133 \\
& & Reverse & CTAGTCGTGACCAGCCGTTT & \\
Desaturase & AF301910 & Forward & ACCTAGTGGCTCCTCTGGTC & 119 \\
& & Reverse & CAGATCCCCTGACTTCTTCA & \\
Elongase & AY605100 & Forward & GAACAGCTTCATCCATGTCC & 149 \\
& & Reverse & TGACTGCACATATCGTCTGG & \\
Elongation factor 1 $\alpha$ & AF498320 & Forward & GAATTCTCCTCCCACAGGAT & 119 \\
& & Reverse & ACGATGGGTTTTAATCAGCA & \\
Actin & AJ438158 & Forward & CAAGCAGGAGTACGACGAGT & 110 \\
& & Reverse & CTGAAGTGGTAGTCGGGTGT & \\
GAPDH & AB066373 & Forward & GTCTCAGTGGTGGACCTGAC & 149 \\
& & Reverse & GCCGTTGAAGTCTGAAGAGA & \\
\hline
\end{tabular}

All genes are from rainbow trout.

CPT-I, carnitine palmitoyltransferase-I; GAPDH, glyceraldehyde 3-phosphate dehydrogenase. 
Table 4. Growth and biometric parameters of rainbow trout (Oncorhynchus mykiss) fed diets containing conjugated linoleic acid (CLA) and tetradecylthioacetic acid (TTA)

\begin{tabular}{lcccc}
\hline & FO & CLA1 & CLA2 & TTA \\
\hline Initial weight $(\mathrm{g})$ & $429 \pm 17$ & $437 \pm 2$ & $450 \pm 8$ & $433 \pm 12$ \\
Final weight $(\mathrm{g})$ & $755 \pm 46$ & $760 \pm 7$ & $777 \pm 15$ & $762 \pm 21$ \\
SGR & $1.06 \pm 0.07$ & $1.08 \pm 0.07$ & $1.02 \pm 0.02$ & $1.05 \pm 0.03$ \\
FCR & $0.99 \pm 0.06$ & $0.95 \pm 0.08$ & $1.03 \pm 0.02$ & $0.98 \pm 0.01$ \\
Gutted weight $(\%)$ & $83.7 \pm 0.8$ & $84.3 \pm 0.7$ & $84.6 \pm 0.7$ & $83.3 \pm 0.6$ \\
Condition factor $(\mathrm{K})$ & $1.58 \pm 0.02$ & $1.58 \pm 0.02$ & $1.62 \pm 0.04$ & $1.58 \pm 0.03$ \\
HSI & $1.4 \pm 0.1$ & $1.4 \pm 0.1$ & $1.3 \pm 0.1$ & $1.5 \pm 0.1$ \\
VSI & $17.0 \pm 1.1$ & $15.7 \pm 0.7$ & $15.4 \pm 0.7$ & $16.7 \pm 0.6$ \\
Pigmentation & $12.6 \pm 0.4$ & $12.8 \pm 0.5$ & $12.8 \pm 0.3$ & $12.6 \pm 0.4$ \\
Mortality (n) & 0 & 0 & 0 & 0 \\
\hline
\end{tabular}

All data are means \pm S.D. with the triplicate tanks being the experimental units $(n=3)$.

$\mathrm{FCR}$, feed conversion ratio $=$ feed consumed $(\mathrm{kg}) /$ weight gain $(\mathrm{kg})$;

HSI, Hepato-somatic index $=100 \times$ liver weight $\mathrm{x}$ body weight ${ }^{-1}$;

Pigmentation, Fillet $\alpha$ value (redness) as measured by Minolta (arbitrary units);

SGR, specific growth rate $(\% /$ day $)=100 \times$ [(Final Weight $/$ Initial Weight $) /$ Days $\left.^{-1}\right]$;

VSI, Viscero-somatic index $=100 \mathrm{x}$ viscera weight $\mathrm{x}$ body weight ${ }^{-1}$;

There were no significant effects of dietary treatment as determined by ANOVA as described in the Materials and Methods. 
Table 5. Lipid content (percentage of wet weight) and polar/neutral lipid compositions (percentage of total lipid) of liver and flesh of rainbow trout (Oncorhynchus mykiss) fed conjugated linoleic acid (CLA) and tetradecylthioacetic acid (TTA)

\begin{tabular}{|c|c|c|c|c|}
\hline Lipid class & FO & CLA 1 & CLA2 & TTA \\
\hline \multicolumn{5}{|l|}{$\underline{\text { Liver }}$} \\
\hline Lipid content & $4.5 \pm 0.1^{\mathrm{a}}$ & $3.7 \pm 0.3^{\mathrm{c}}$ & $3.9 \pm 0.4^{b c}$ & $4.3 \pm 0.4^{\mathrm{ab}}$ \\
\hline Total polar & $37.6 \pm 2.0$ & $40.2 \pm 3.7$ & $41.3 \pm 3.0$ & $42.3 \pm 2.6$ \\
\hline Total neutral & $62.4 \pm 2.0$ & $59.8 \pm 3.7$ & $58.7 \pm 3.0$ & $57.7 \pm 2.6$ \\
\hline \multicolumn{5}{|l|}{ Flesh } \\
\hline Lipid content & $7.2 \pm 0.6$ & $7.2 \pm 0.3$ & $7.7 \pm 0.5$ & $8.2 \pm 1.0$ \\
\hline Total polar & $12.4 \pm 3.3$ & $12.3 \pm 1.9$ & $11.2 \pm 0.9$ & $9.5 \pm 1.1$ \\
\hline Total neutral & $87.6 \pm 3.3$ & $87.7 \pm 1.9$ & $88.8 \pm 0.9$ & $90.5 \pm 1.1$ \\
\hline
\end{tabular}

Values are means \pm SD of 6 samples each of tissue pooled from 3 fish.

Superscript letters denote significant differences between dietary treatments as determined by ANOVA as described in the Materials and Methods. 
Table 6. Fatty acid composition (percentage of weight) of total lipid from liver of rainbow trout (Oncorhynchus mykiss) fed conjugated linoleic acid (CLA) and tetradecylthioacetic acid (TTA)

\begin{tabular}{|c|c|c|c|c|}
\hline & FO & CLA1 & CLA2 & TTA \\
\hline $14: 0$ & $2.0 \pm 0.2$ & $1.8 \pm 0.2$ & $1.8 \pm 0.1$ & $1.8 \pm 0.1$ \\
\hline $16: 0$ & $13.1 \pm 1.1^{\mathrm{a}}$ & $12.6 \pm 1.0^{\mathrm{a}}$ & $12.2 \pm 0.5^{\mathrm{ab}}$ & $10.8 \pm 1.1^{\mathrm{b}}$ \\
\hline 18:0 & $8.2 \pm 0.3^{\mathrm{d}}$ & $13.4 \pm 0.5^{b}$ & $14.8 \pm 0.5^{\mathrm{a}}$ & $9.6 \pm 0.4^{\mathrm{c}}$ \\
\hline Total saturated $^{1}$ & $23.7 \pm 1.3^{b}$ & $28.3 \pm 1.1^{\mathrm{a}}$ & $29.3 \pm 0.5^{\mathrm{a}}$ & $22.6 \pm 1.4^{b}$ \\
\hline $16: 1 n-7$ & $4.7 \pm 0.4^{\mathrm{a}}$ & $2.8 \pm 0.3^{b c}$ & $2.6 \pm 0.2^{\mathrm{c}}$ & $3.2 \pm 0.3^{b}$ \\
\hline $18: \ln -9$ & $17.7 \pm 2.0^{\mathrm{a}}$ & $10.8 \pm 1.8^{b c}$ & $9.0 \pm 0.9^{\mathrm{c}}$ & $12.2 \pm 1.6^{b}$ \\
\hline $18: 1 n-7$ & $3.4 \pm 0.1^{\mathrm{a}}$ & $2.7 \pm 0.2^{b}$ & $2.6 \pm 0.1^{b}$ & $3.5 \pm 0.2^{\mathrm{a}}$ \\
\hline $20: 1 n-9$ & $2.3 \pm 0.3^{\mathrm{a}}$ & $1.9 \pm 0.3^{b}$ & $1.5 \pm 0.1^{\mathrm{c}}$ & $2.6 \pm 0.2^{\mathrm{a}}$ \\
\hline $24: 1 n-9$ & $0.4 \pm 0.0$ & $0.5 \pm 0.1$ & $0.5 \pm 0.1$ & $0.5 \pm 0.1$ \\
\hline Total monoenes ${ }^{2}$ & $29.0 \pm 2.2^{\mathrm{a}}$ & $19.1 \pm 2.2^{\mathrm{c}}$ & $16.8 \pm 1.2^{\mathrm{c}}$ & $22.5 \pm 2.2^{b}$ \\
\hline CLA $(9 c, 11 t)$ & $0.0 \pm 0.0^{\mathrm{c}}$ & $0.4 \pm 0.1^{b}$ & $0.7 \pm 0.0^{\mathrm{a}}$ & $0.0 \pm 0.0^{\mathrm{c}}$ \\
\hline CLA $(10 t, 12 \mathrm{c})$ & $0.0 \pm 0.0^{\mathrm{c}}$ & $0.2 \pm 0.0^{b}$ & $0.4 \pm 0.0^{\mathrm{a}}$ & $0.0 \pm 0.0^{\mathrm{c}}$ \\
\hline TTA & $0.0 \pm 0.0^{\mathrm{b}}$ & $0.0 \pm 0.0^{b}$ & $0.0 \pm 0.0^{b}$ & $0.9 \pm 0.1^{\mathrm{a}}$ \\
\hline $18: 2 n-6$ & $1.7 \pm 0.1^{\mathrm{ab}}$ & $1.5 \pm 0.1^{\mathrm{c}}$ & $1.6 \pm 0.1^{b c}$ & $1.8 \pm 0.1^{\mathrm{a}}$ \\
\hline $20: 4 n-6$ & $2.2 \pm 0.2^{b}$ & $3.0 \pm 0.4^{\mathrm{a}}$ & $2.9 \pm 0.2^{\mathrm{a}}$ & $3.1 \pm 0.4^{\mathrm{a}}$ \\
\hline $22: 4 n-6$ & $0.6 \pm 0.0$ & $0.6 \pm 0.1$ & $0.6 \pm 0.1$ & $0.6 \pm 0.1$ \\
\hline Total n-6 PUFA ${ }^{3}$ & $5.2 \pm 0.4^{\mathrm{b}}$ & $6.0 \pm 0.5^{\mathrm{a}}$ & $5.8 \pm 0.3^{a b}$ & $5.8 \pm 0.3^{a b}$ \\
\hline $18: 3 n-3$ & $0.5 \pm 0.1$ & $0.5 \pm 0.0$ & $0.5 \pm 0.1$ & $0.6 \pm 0.0$ \\
\hline $20: 4 n-3$ & $0.6 \pm 0.1^{\mathrm{b}}$ & $0.6 \pm 0.0^{b}$ & $0.7 \pm 0.1^{b}$ & $0.9 \pm 0.2^{\mathrm{a}}$ \\
\hline $20: 5 n-3$ & $9.4 \pm 0.4^{\mathrm{b}}$ & $10.2 \pm 0.7^{\mathrm{ab}}$ & $10.5 \pm 0.5^{\mathrm{a}}$ & $9.6 \pm 0.5^{b}$ \\
\hline $22: 5 n-3$ & $3.7 \pm 0.4^{b}$ & $3.6 \pm 0.4^{b}$ & $3.6 \pm 0.3^{b}$ & $4.9 \pm 0.7^{\mathrm{a}}$ \\
\hline $22: 6 n-3$ & $27.7 \pm 1.2$ & $31.0 \pm 1.8$ & $31.5 \pm 1.6$ & $31.8 \pm 1.0$ \\
\hline Total n-3 PUFA & $42.2 \pm 1.8^{b}$ & $46.1 \pm 1.9^{\mathrm{a}}$ & $47.0 \pm 1.4^{\mathrm{a}}$ & $48.2 \pm 1.0^{\mathrm{a}}$ \\
\hline Total PUFA & $47.3 \pm 2.1^{\mathrm{b}}$ & $52.0 \pm 1.9^{\mathrm{a}}$ & $52.9 \pm 1.5^{\mathrm{a}}$ & $53.9 \pm 1.1^{\mathrm{a}}$ \\
\hline$n-3 / n-6$ & $8.2 \pm 0.4$ & $7.8 \pm 0.7$ & $8.1 \pm 0.3$ & $8.4 \pm 0.5$ \\
\hline
\end{tabular}

Values are means \pm SD of 6 samples each of tissue pooled from 3 fish. A

0.0 denotes a value of $<0.05$. Superscript letters denote significant differences between dietary treatments as determined by ANOVA as described in the Materials and Methods. PUFA, polyunsaturated fatty acids.

${ }^{1}$, includes 15:0 and 20:0, present in some samples at up to $0.2 \%$.

${ }^{2}$, includes $20: 1 \mathrm{n}-7$ and $22: 1 \mathrm{n}-11$, present in some samples at up to $0.3 \%$.

${ }^{3}$, includes 20:2n-6 and 20:3n-6 present in some samples at up to $0.4 \%$.

${ }^{4}$, includes $18: 4 n-3$ and $20: 3 n-3$ present in some samples at up to $0.2 \%$. 
Table 7. Fatty acid composition (percentage of weight) of total lipid from flesh of rainbow trout (Oncorhynchus mykiss) fed conjugated linoleic acid (CLA) and tetradecylthioacetic acid (TTA)

\begin{tabular}{|c|c|c|c|c|}
\hline & FO & CLA1 & CLA2 & TTA \\
\hline $14: 0$ & $5.9 \pm 0.4$ & $5.6 \pm 0.3$ & $5.8 \pm 0.2$ & $5.9 \pm 0.4$ \\
\hline $15: 0$ & $0.6 \pm 0.0$ & $0.6 \pm 0.0$ & $0.6 \pm 0.0$ & $0.6 \pm 0.0$ \\
\hline $16: 0$ & $19.1 \pm 0.6$ & $18.9 \pm 0.4$ & $18.9 \pm 0.4$ & $18.9 \pm 0.4$ \\
\hline $18: 0$ & $4.4 \pm 0.3^{b}$ & $5.3 \pm 0.2^{\mathrm{a}}$ & $5.0 \pm 0.5^{\mathrm{a}}$ & $4.4 \pm 0.1^{\mathrm{b}}$ \\
\hline Total saturated & $30.0 \pm 1.2$ & $30.2 \pm 0.7$ & $30.2 \pm 0.8$ & $29.8 \pm 0.7$ \\
\hline $16: 1 n-7$ & $7.2 \pm 0.4$ & $6.8 \pm 0.1$ & $6.9 \pm 0.2$ & $7.0 \pm 0.2$ \\
\hline $18: 1 n-9$ & $13.4 \pm 0.6^{\mathrm{a}}$ & $12.4 \pm 0.4^{\mathrm{b}}$ & $12.7 \pm 0.2^{b}$ & $12.8 \pm 0.6^{\mathrm{ab}}$ \\
\hline $18: 1 n-7$ & $3.5 \pm 0.1$ & $3.5 \pm 0.1$ & $3.4 \pm 0.1$ & $3.6 \pm 0.1$ \\
\hline $20: 1 n-9$ & $2.8 \pm 0.3^{\mathrm{ab}}$ & $2.5 \pm 0.3^{b}$ & $3.1 \pm 0.2^{\mathrm{a}}$ & $2.8 \pm 0.3^{a b}$ \\
\hline $22: \ln -11$ & $2.5 \pm 0.4^{\mathrm{ab}}$ & $2.2 \pm 0.3^{b}$ & $2.9 \pm 0.2^{\mathrm{a}}$ & $2.4 \pm 0.4^{\mathrm{ab}}$ \\
\hline $24: 1 n-9$ & $0.4 \pm 0.0$ & $0.4 \pm 0.0$ & $0.4 \pm 0.0$ & $0.4 \pm 0.1$ \\
\hline Total monoenes ${ }^{1}$ & $30.1 \pm 0.5^{a}$ & $28.1 \pm 0.9^{b}$ & $29.7 \pm 0.5^{a}$ & $29.3 \pm 0.8^{a}$ \\
\hline CLA $(9 c, 11 t)$ & $0.0 \pm 0.0^{\mathrm{c}}$ & $0.6 \pm 0.1^{\mathrm{b}}$ & $0.9 \pm 0.2^{\mathrm{a}}$ & $0.0 \pm 0.0^{\mathrm{c}}$ \\
\hline CLA $(10 t, 12 c)$ & $0.0 \pm 0.0^{\mathrm{c}}$ & $0.5 \pm 0.1^{\mathrm{b}}$ & $0.7 \pm 0.1^{\mathrm{a}}$ & $0.0 \pm 0.0^{\mathrm{c}}$ \\
\hline TTA & $0.0 \pm 0.0^{b}$ & $0.0 \pm 0.0^{\mathrm{b}}$ & $0.0 \pm 0.0^{b}$ & $1.2 \pm 0.1^{\mathrm{a}}$ \\
\hline $18: 2 n-6$ & $4.8 \pm 0.8$ & $5.5 \pm 0.7$ & $4.6 \pm 0.3$ & $5.4 \pm 0.9$ \\
\hline $20: 4 n-6$ & $0.9 \pm 0.0$ & $1.0 \pm 0.0$ & $0.9 \pm 0.0$ & $0.9 \pm 0.0$ \\
\hline Total n-6 PUFA & $6.7 \pm 0.8$ & $7.5 \pm 0.7$ & $6.4 \pm 0.3$ & $7.0 \pm 0.9$ \\
\hline $18: 3 n-3$ & $1.2 \pm 0.2$ & $1.2 \pm 0.0$ & $1.2 \pm 0.1$ & $1.3 \pm 0.1$ \\
\hline $18: 4 n-3$ & $1.5 \pm 0.1$ & $1.4 \pm 0.1$ & $1.6 \pm 0.1$ & $1.5 \pm 0.1$ \\
\hline $20: 4 n-3$ & $1.3 \pm 0.1$ & $1.3 \pm 0.1$ & $1.1 \pm 0.2$ & $1.4 \pm 0.2$ \\
\hline $20: 5 n-3$ & $8.7 \pm 0.3$ & $8.7 \pm 0.2$ & $8.4 \pm 0.2$ & $8.5 \pm 0.2$ \\
\hline $22: 5 n-3$ & $2.9 \pm 0.1$ & $2.9 \pm 0.0$ & $2.7 \pm 0.1$ & $3.0 \pm 0.2$ \\
\hline $22: 6 n-3$ & $17.3 \pm 1.1$ & $17.5 \pm 0.4$ & $16.8 \pm 0.5$ & $16.8 \pm 0.6$ \\
\hline Total n-3 PUFA & $33.2 \pm 1.2$ & $33.2 \pm 0.3$ & $32.0 \pm 0.8$ & $32.8 \pm 0.7$ \\
\hline Total PUFA & $39.9 \pm 1.1^{\mathrm{a}}$ & $40.7 \pm 0.8^{a}$ & $38.5 \pm 0.5^{b}$ & $39.7 \pm 0.7^{\mathrm{ab}}$ \\
\hline$n-3 / n-6$ & $5.0 \pm 0.7$ & $4.5 \pm 0.4$ & $5.0 \pm 0.3$ & $4.8 \pm 0.6$ \\
\hline
\end{tabular}

Values are means \pm SD of 6 samples each of tissue pooled from 3 fish. An SD of 0.0 denotes a value of $<0.05$. Superscript letters denote significant differences between dietary treatments as determined by ANOVA as described in the Materials and Methods. PUFA, polyunsaturated fatty acids.

${ }^{1}$, includes $20: 1 \mathrm{n}-7$ present in some samples at up to $0.3 \%$.

${ }^{2}$, includes 20:2n-6, 20:3n-6 and 22:4n-6 present in some samples at up $0.3 \%$.

3 , includes $20: 3 n-3$ present at up to $0.3 \%$. 
Fig.1

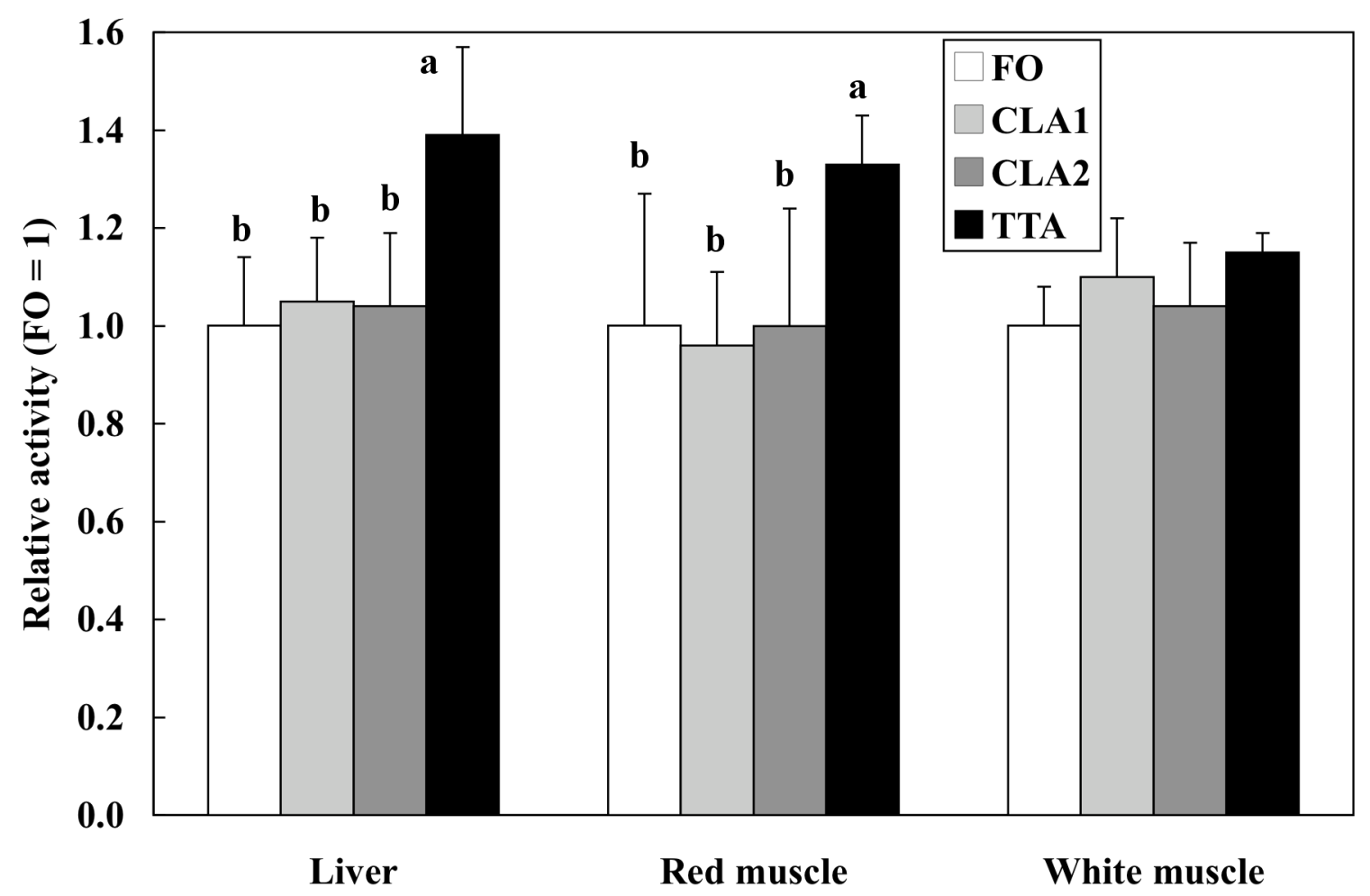


Fig.2

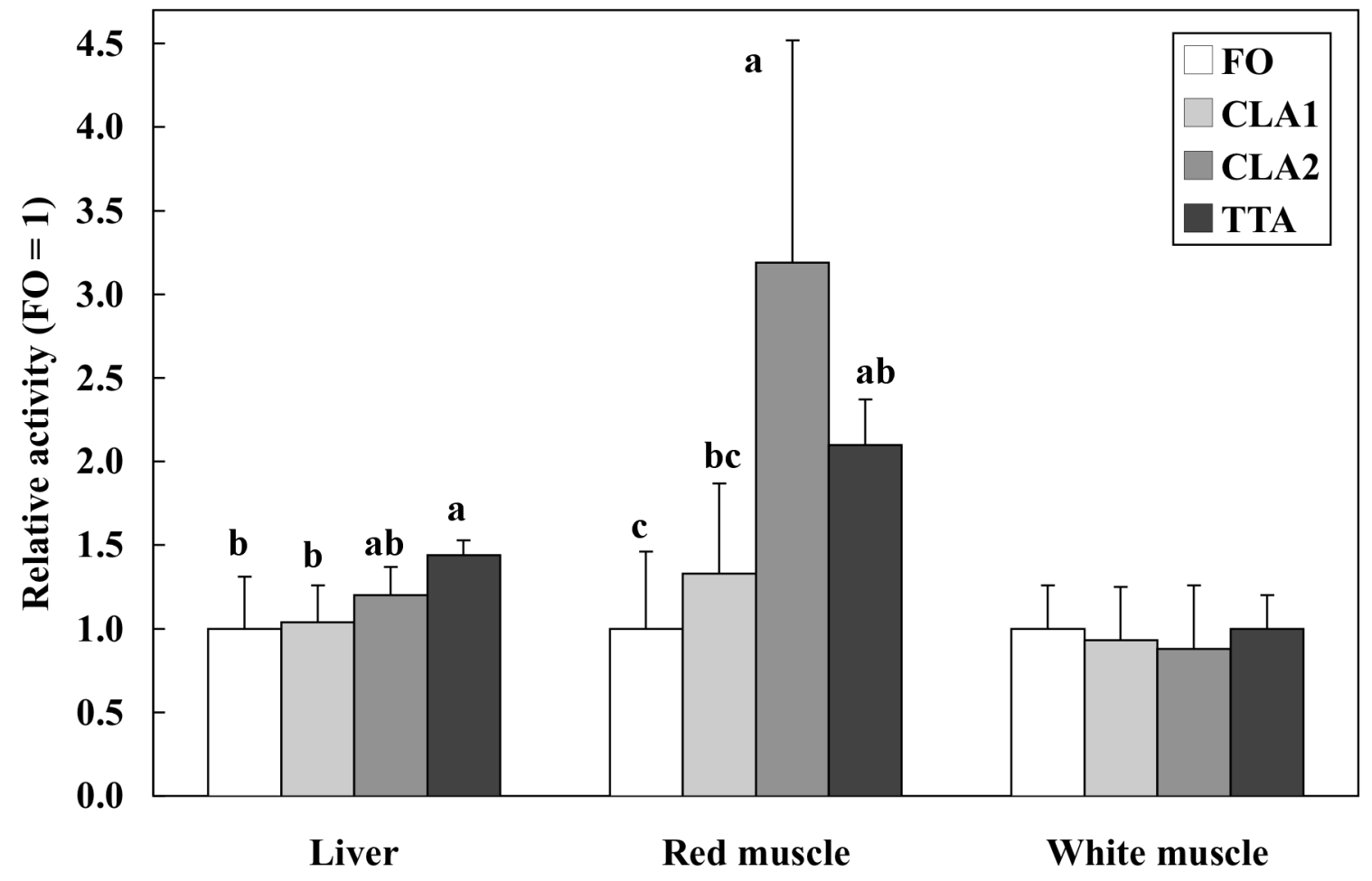


Fig.3

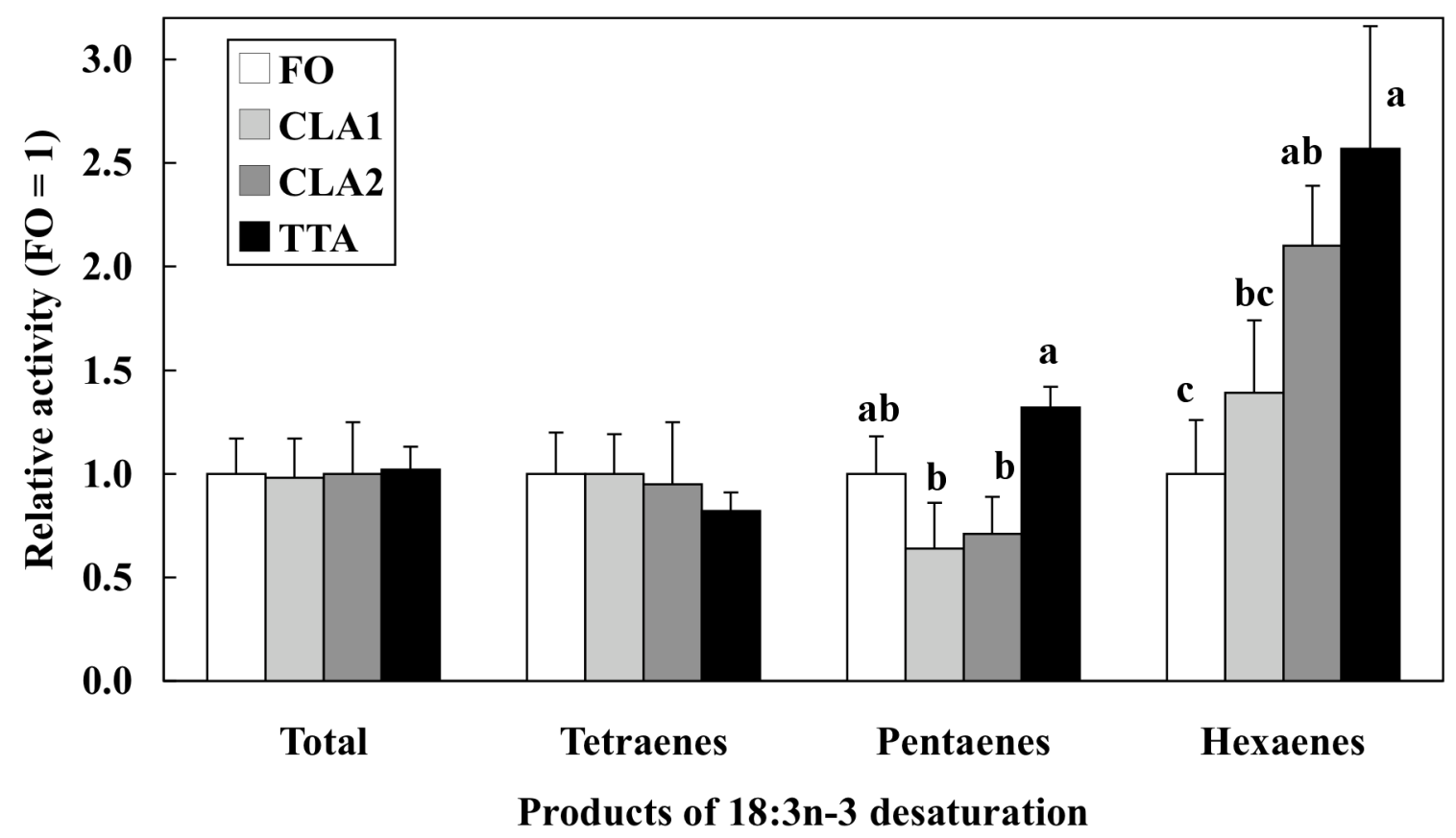


Fig.4

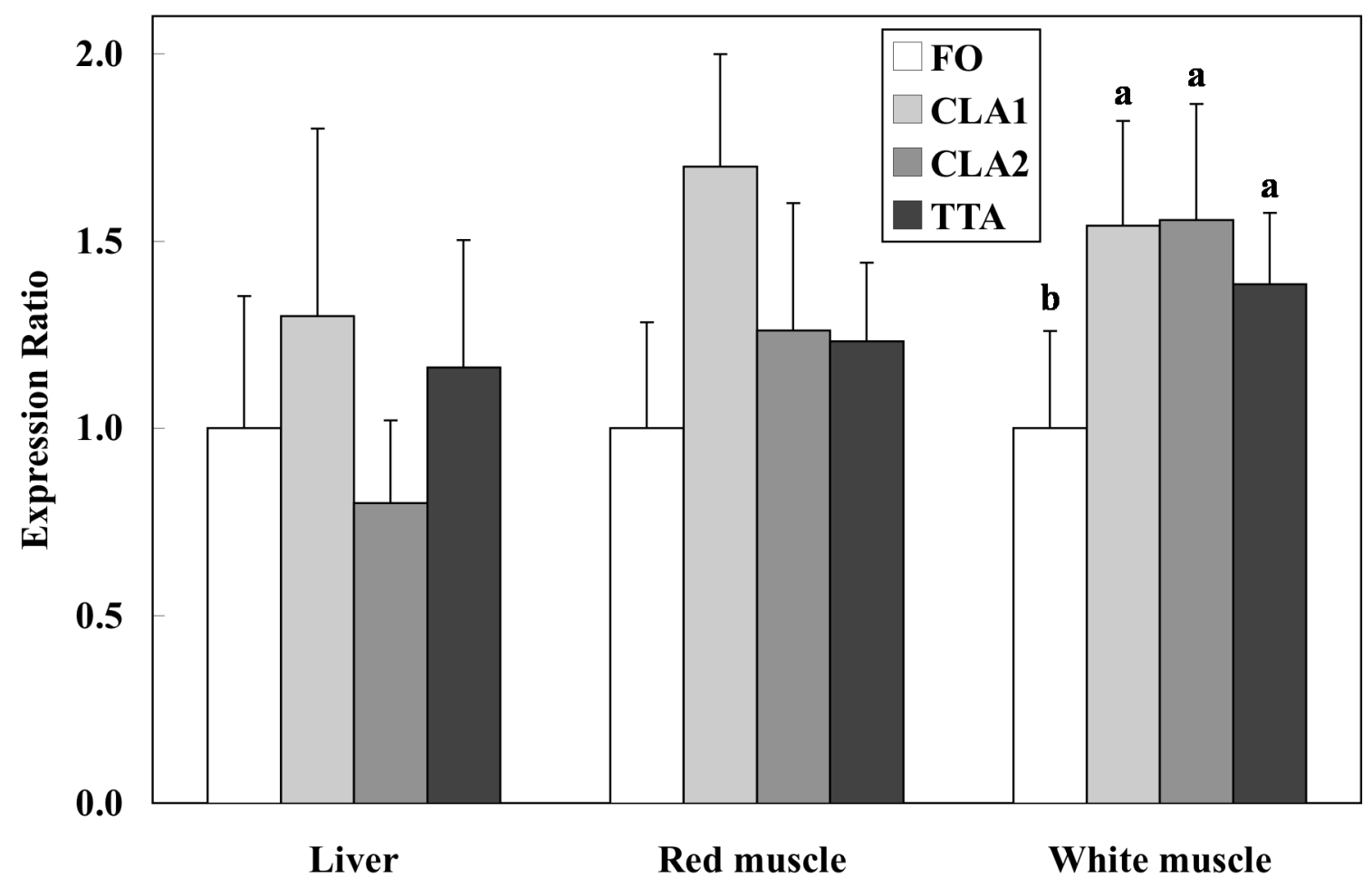


Fig.5

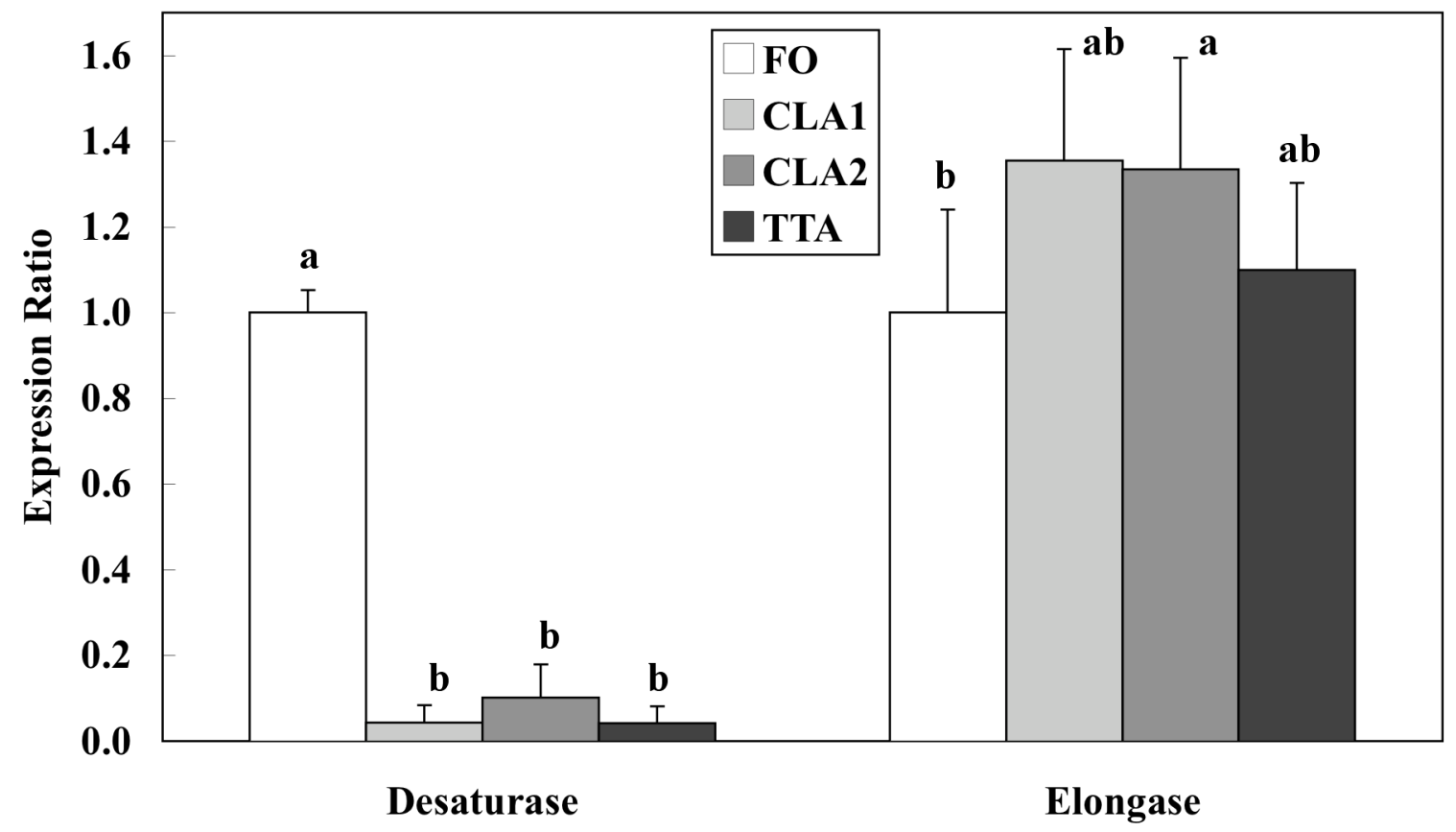

